\title{
Mapping the evolution of the central government apparatus in China
}

\author{
Liang Ma, liangma@ruc.edu.cn \\ Associate Professor, School of Public Administration and Policy, Renmin University of \\ China, China
Tom Christensen, tom.christensen@stv.uio.no
Professor of Public Administration and Policy, Department of Political Science, University of Oslo, Norway
Visiting Professor, School of Public Administration and Policy, Renmin University of China, China

Correspondence should go to Tom Christensen at tom.christensen@ stv.uio.no.

Acknowledgements: An earlier version of this paper was presented at the 2017 ASPA Annual Conference "Saluting the Public Service: A Bold and Noble Profession," March 17-21, Atlanta, GA. The authors would like to thank Zidian Sun and his team for excellent assistance in data coding. Financial support was provided by the Fundamental Research Funds for the Central Universities and the Research Funds of Renmin University of China (No.: 16XNB005). 


\title{
Mapping the evolution of the central government apparatus in China
}

\begin{abstract}
The structure of political and administrative institutions is important for achieving public goals. It is not fixed, however, but may change as a result of environmental and cultural processes or because of changes in leadership. Structural changes in the central government apparatus feature prominently in the recent strand of reform and change literature, but we know little about structural changes in contexts other than Western democracies. In this paper, we analyze the main types of and possible reasons for structural changes in the central governmenta apparatus in China over the past seventy years. We find interesting patterns of structural change in line with administrative developments. Using the multiple perspectives of organization theory, these can be primarily explained by political cycles or action taken by the central leadership, but they have also been influenced by cultural elements, economic growth, and societal transformation. .
\end{abstract}

\section{Points for practitioners}

We document the key patterns of organizational restructuring in China's central government from 1949 to 2016. Political cycles and economic reform and development are found to be the key drivers of structural evolution. The results show that the political will of top leaders plays a crucial role in navigating structural reforms, yet institutional reforms are still largely confined to rhetoric and symbolism without substantively transforming the landscape of government architecture. Sustained structural reforms are difficult to achieve successfully, which suggests that alternative avenues may be required to streamline administrative processes and improve interagency coordination.

\section{Keywords}

Central government, organizational structure, evolution, public sector reform, China 


\section{Introduction}

Political science is basically a 2000-year-old tradition of studying a special type of formal organization, namely, the public institutions in the political-administrative system (Wolin, 2009). In his study of the federal government in the US, Gulick (1937) arrived at the basic insight that public goals could be realized through a systematic structural design of the public apparatus. Schattschneider (1960) pointed out that 'organization is mobilization of bias', meaning that certain formal organizational structures systematically organize in certain actors, problems, and solutions (Schattschneider, 1960), while others are organized out (Weaver and Rockman, 1993).

This structurally oriented strand of studies is also reflected in the extensive reform literature, which primarily focuses on the New Public Management (NPM) and postNPM reforms of the past three decades (Christensen and Lægreid 2001). The focus of analyses in these studies is both how various reform waves are based on ideas about the formal structure of public organizations - NPM focuses on devolution and fragmentation while post-NPM espouses centralization and coordination - but also how executive leaders and other stakeholders struggle to preserve or change certain government structures (Pollitt and Bouckaert, 2011).

Internationally, the most researched type of public organization, whether the focus is on development, functioning or effects, is the government agency. The COST Action and the Cobra data base, financed by the EU and located in Leuven, which have compared twenty-three European countries and later included countries from most parts of the world, is the most impressive effort so far in this field (Verhoest, Van Thiel, Bouckaert, and Lægreid, 2012). The birth, survival, and death of government agencies in the US (Lewis, 2002), the Netherlands (Boin, Kuipers, and Steenbergen, 2010), the UK (James, Petrovsky, Moseley, and Boyne, 2016), and Norway (Rolland and Roness, 2010, 2011, 2012), for instance, have been extensively examined. The rather recent strand of studies tracing the creation, change, and termination of central government organizations must be understood in terms of both the long-term structural tradition and the short-term focus on agencies (Kuipers, Yesilkagit, and Carroll, 2017). 
Historically, the structure of institutions in the political-administrative system is important for achieving public goals. This structure may, however, change as a result of environmental change, gradual and long-term cultural processes or conscious efforts by political and administrative executive leaders. Over the past decade the reform and change literature has emphasized structural changes in the central government apparatus. The present article follows this tradition and focuses on structural changes in a context different to that of Western democracies, namely, the central government apparatus in the one-party state of China over the past seventy years. Structural change in central government organizations has been investigated in both presidential and parliamentary systems in the West, but we know little about its variations in authoritarian systems like China (one-party and unitary) (Ma, 2016).

China is worth studying, not only because of its very long bureaucratic traditions, but also because of its extremely complex central administrative structure, which is only partly comparable with those in the West (Christensen, Dong, and Painter, 2008). The strong party leadership, for instance, means that restructuring is relatively easy to initiate and sustain. Also, the developing and transitional nature of the regime suggests that reorganizations will be more frequent and more radical than in mature societies. The constellation of the central government apparatus has been reformed back and forth ever since the founding of the People's Republic of China in 1949 (Dong, Christensen, and Painter, 2010). A total of thirteen rounds of institutional reforms have been implemented, with six before and seven after the Reform and Opening-up in 1978. Central agency restructuring in China is of paramount importance, because parallel agencies at all four local levels (province, prefecture, county, and town) have to mirror it in an almost unitary manner.

Our main research questions are, accordingly:

- What characterizes the structural changes in the central government apparatus in China over the past seventy years?

- What could be some major plausible reasons driving this structural change? 
using case studies (Pearson, 2007), but to our knowledge there has been no quantitative analysis documenting the historical evolution of the central state apparatus. In this article, we adapt the coding scheme of the Norwegian State Administration Database (NSAD) (Rolland and Roness, 2012) to map changes in Chinese central government. We identify the key patterns of restructuring in central government and use political cycles, economic reform and development, and other variables to explain the variations in organizational restructuring. Our aim in this article is to undertake a first descriptive examination of the Chinese data and focus on some plausible reasons for organizational change; later we will go into the comparative aspects in more detail.

We start by reviewing the theory and studies of governmental change and introduce the context of administrative reform and structural change in China over the past half century. We then present the data and methods used in our study, followed by our empirical findings and analysis.

\section{Theoretical perspectives}

\section{Explaining structural change in government}

The main factors explaining structural change in government are captured by the transformative model of Christensen and Lægreid (2001), which contains the same major elements as Pollitt and Bouckaert's (2011) broad comparative study of structural change and reforms. The transformative model starts by focusing on environmental factors, of which there are basically two types, technical and institutional (Meyer and Rowan, 1977). Structural change based on the technical environment can be related to broad political, economic, social, or other factors, while institutional change may be connected to myths and symbols about how the public sector should be organized (Brunsson 1989). If the changes are based on ideas spread by international organizations, like the OECD, the EU, the UN, the IMF, etc. this may endow political and administrative leaders with more legitimacy (Brunsson, 1989; Sahlin-Andersson, 2001). In our case, economic growth in China or imitation of the West may lead to structural change (Christensen, et al., 2008). 
The second element of the model is the cultural norms and values that develop in processes of institutionalization over a long period of time in a path-dependent fashion, which give public organizations unique identities (Selznick, 1957). Often, professional groups like civil servants will play an important role in preserving and gradually developing cultural traditions that influence structural change. But cultural shocks of a more general societal nature may also lead to structural change (Kingdon, 1984).We pursue both these versions of the cultural perspective, focusing on continuity and breaks in the structural path of China's central civil service.

A third set of important factors are the polity ones, meaning political and administrative actors in the public apparatus who consciously try to further structural change within constitutional and other formal constraints. According to March and Olsen (1983), this can be done in two ways, either through hierarchical processes, dominated by top executive leaders with clear aims, or through processes of negotiation where there is heterogeneity in actor patterns, problems, and solutions, and compromises often have to be reached. In a centralized one-party state like China, with tensions in the leadership, we expect this perspective to represent a major element behind central structural change.

The transformative model also addresses the dynamics between the three sets of plausible reasons outlined (Christensen and Lægreid, 2001). Kingdon (1984) formulates the argument that policy entrepreneurs may be able to 'pry open' and 'jump through' a 'window of opportunity' created by external factors that often launch the political-administrative apparatus on a new structural or cultural path (Kingdon, 1984); this was the case with the reforms and changes in New Zealand from 1983 on (Aberbach and Christensen, 2001). In her study of the Meiji period in Japan from 1860 to 1912 , Westney (1987) focused on the authorities as 'rational shoppers' abroad, picking successful change models, but adapting them to Japanese cultural traditions (Westney, 1986). Olsen (1992) sees external change signals as filtered through cultural traditions, working as constraints on the actions of executive leaders (Olsen, 1992). In the Chinese case we would expect the political leadership's changing priorities to be the main dynamic behind structural change, while general societal factors and cultural processes 
in the apparatus might enhance or modify the impact of these.

Agency change

More specific plausible reasons for agency change often reflect the more general reasons alluded to above, but they also deepen those and are hence useful in our broader study. Lewis (2002: 91-92) focuses primarily on polity factors when trying to explain agency change in the US. He talks about the dynamics of coalitions trying to establish or abolish agencies, the need to cut costs and to compete with other public organizations for budgets, about agency failure, and about political opposition and political turn-over.

Adam et al. (2007: 222-226) use a broad set of explanations, starting with the famous Kaufman’s (1976) 'immortality myth’ and its empirical criticism (Adam, Bauer, Knill, and Studinger, 2007). This explanation is basically a cultural one, emphasizing path-dependency and the resilience of public organizations. Boin et al. (2010) also start with the Kaufman-inspired 'impressive durability' thesis (Carpenter and Lewis, 2004: 203), which they discuss in relation to empirical studies showing public organizations to be both durable and mortal. They examine two sets of plausible reasons as alternatives. First, they look at the environmental dynamics that create opportunities for structural change, which might include political turnover, policy entrepreneurs, and windows of opportunity. The second set of reasons concerns birth characteristics, 'hardwiring', and structural insulation, which make public organizations difficult to terminate. These reasons are partly cultural in the sense that they increase the probability of the path chosen being resilient, but they are also instrumental.

Government agencies are man-made entities and thus not immortal (Kaufman, 1976), and they vary substantially in how long they survive (Lewis, 2002). Some agency changes consist merely of rhetoric and symbolism, but most involve substantial variations in power sharing, resource allocation, and program management (Aberbach and Christensen, 2014). 


\section{Context and methods}

\section{The context of central governmental change in China}

China is governed by a single ruling party (Communist Party of China, CPC) and organized according to a unitary system (rather than a federal system), which means that the administrative structure is substantially the same at all levels. There are four administrative tiers below the State Council (SC) at the central level (the cabinet): province, prefecture, county, and municipality. All four levels are subordinate to the central level, and local governments have a varying amount of administrative autonomy, while their organizational structures are substantially the same. Our focus in this study is on the various units in the central governmental apparatus rather than on local government, which has been extensively examined (Ma, 2016). Although there are variations across regions and levels, our findings on the central apparatus may potentially be generalized to local government.

Organizational restructuring is central to public sector reform in China, which has been repeatedly used as leverage to change other aspects of government operations, e.g., functions, coordination, and workforce (Christensen, et al., 2008). The State Commission Office for Public Sector Reform (SCOPSR) is in charge of institutional reform and organizational restructuring, and almost every term of office (usually five years) has witnessed significant government reorganization. Apart from occasional restructuring, a total of thirteen rounds of major institutional reforms have been implemented so far, with six (1951-1953, 1954-1956, 1956-1959, 1960-1965, 19661975, and 1976-1981) before and seven after the Reform and Opening-up in 1978 (1982, 1988, 1993, 1998, 2003, 2008, and 2013).

The core purpose of organizational restructuring is to reduce the number of units like ministries, commissions, and agencies, to transform government functions, and to downsize the civil service. Government agencies are often transformed into public service institutions or state-owned enterprises (SOEs) affiliated with their former superior organizations. Deng Xiaoping once said "institutional reform is a revolution". 
Such reforms have repeatedly failed, however, contributing to vicious circles of restructuring. Mandatory reforms often have made superficial changes without fundamentally transforming the government architecture, and new and revamped units have proliferated soon after restructuring (Christensen, et al., 2008). It is thus interesting to examine organizational change in the central government apparatus in China.

The scope of central government organizational units

In mapping central state organizations, it is important to decide "who is in and who is out" in multiple dimensions, e.g., permanent/temporary, ownership, and government level (Rolland and Roness, 2010: 464). The government apparatus is structured hierarchically and we focus on central organizational units at the ministry, vice-ministry, and bureau level directly subordinate to the SC, excluding subunits within the entities (e.g., departments and divisions). We only include permanent organs composing the SC (ministries, commissions, agencies, bureaus, and offices), while temporary joint taskforces and ad hoc cross-ministry committees are excluded from our dataset. Although the internal organization of these agencies also merits examination, we exclude them because the data on internal organization are not sufficient. Instead, we focus on specific units to explore their subordinate departments via case studies. For instance, the Ministry of Environmental Protection (MOE) has restructured its departments according to pollutants (i.e., air, water, and soil pollutants) instead of according to pollution control procedures (i.e., pre and post) as previously in 2016.

We exclude SOEs from our analysis, which are also numerous and not well documented in existing government material. We do, however, include public service units (shiye danwei) in our analysis of the government apparatus, which are equivalent in function but different from the civil service administration. We exclude departments of the Central Committee of the CPC (CCCPC) from our study, since its organization has not varied much and is different from the government. The departments of the CPC committee (e.g., Department of Organization, Department of Propaganda) are 
juxtaposed with administrative organs at the same level.

\section{Key variables and the codebook}

Instead of developing a new codebook from scratch, we adapted the codebook used to map Norwegian state agencies by NSAD (Rolland and Roness, 2012), which is well designed and implemented. We follow NSAD to define types of state organization (Rolland and Roness, 2010) and to classify the types of organizational change (Rolland and Roness, 2011).

The central government units are classified by the SC into seven categories: (1) the General Office of the SC, (2) ministries (e.g., Ministry of Agriculture) and commissions (e.g., National Development and Reform Commission), (3) offices (e.g., Legislative Affairs Office of the SC), (4) organizations directly under the SC (e.g., National Bureau of Statistics), (5) public service institutions directly under the SC (e.g., China Banking Regulatory Commission), (6) administrations and bureaus subordinate to ministries and commissions (e.g., State Bureau of Civil Servants), and (7) industrial associations (e.g., China Council for the Promotion of International Trade). ${ }^{1}$

These seven types of central government unit vary in terms of origin, affiliation, rank, and function, which is partly reflected in their titles (i.e., ministries, commissions, (special) organizations, offices, state/general administrations, and bureaus). The General Office, steered by the secretary-general, manages the daily operations of the $\mathrm{SC}$, similar to the cabinet office in Western countries. Ministries and commissions are equivalent to ministries in Western countries; as members of the cabinet they are eligible to attend the standing committee of the SC, which makes key policy decisions. ${ }^{2}$ Organizations (e.g., administrations) and offices directly subordinate to the SC are not involved in key policy decision-making, but are primarily responsible for policy implementation and routine affairs, respectively. The state-owned Assets Supervision

\footnotetext{
1 For more examples see State Council Organization Chart. Updated: Aug. 28, 2014. http://english. gov. cn/state_council/2014/09/03/content_281474985533579.htm.

2 China has more ministries and commissions than most Western countries, partly because of its unitary system, large size, complexity, and unprecedented transition.
} 
and Administration Commission is the only special organization directly subordinate to the SC. This is partly due to its salience in controlling over 100 centrally administrated SOEs. Public service institutions are statutory entities rather than state organs, and their employees are not ordinary civil servants, but still public employees. Administrations and bureaus under ministries and commissions are simultaneously subordinate to the SC and relatively independent, and they can report directly to the SC. They are comparable to agencies in Western countries. Industrial associations are autonomous non-profit organizations in charge of international trade and cooperation, but generally they are coordinated by and report to the SC.

There are three tiers of central government: ministry, vice-ministry, and bureau. General office, ministries and commissions, special organizations and organizations, offices, and mass organizations are primarily at ministry level; institutions under the $\mathrm{SC}$ and administrations and bureaus under ministries and commissions are primarily at the vice-ministry and bureau levels.

We have adapted the United Nations (UN) Classification of Functions of Government (COFOG) to classify the functions and policy areas of central government units (Rolland and Roness, 2010), which include foreign policy (defense, foreign affairs, and international development), social policy (civil rights, education, benefits, health, housing, crime, policy for elderly people, and arts), monetary policy (commerce, monetary policy, budgeting, banking, tax, and treasury issues), economic development (macroeconomic management), resources and environment (the exploration, protection and management of all resources and environment), research and consultation (intellectual work and scientific research designed to advance policy suggestions), and general affairs (civil service administration). ${ }^{3}$

Central government units experience various types of change (birth, survival, and

\footnotetext{
3 We recognize that Chinese agency functions are rather complicated, and that functional transformation is therefore of particular concern to decision-makers. We are interested in describing and comparing China with other countries, and a standard protocol would help in this regard. Despite China's uniqueness and complexity, we still believe that a well-established international classification scheme is the best instrument for a cross-national comparison. In coding agencies' functions, we focus on their dominant or primary functions and do not go further into their specific roles.
} 
death), and it is crucial to make the framework flexible. Apart from founding and termination, there are five other types of organizational change, including succession, splitting, absorption, mergers, and complex reorganizations (some combinations of the other four types) (Rolland and Roness, 2011). To these we add changes of function (missions, tasks, or scope of responsibility) and affiliation.

Agencies can be 'born' either via legislation or via executive orders, which may affect the unit's legal status and policy orientation. Legislation passed by the National People's Congress (NPC) delegates statutory authority to units, but legislation is normally used only for major changes. In contrast, routine governmental changes are often decreed by the SC via an executive order, and legal authority is relatively limited. Given the discretion and autonomy of executive orders, units created by them are largely subject to arbitrary control by the SC.

The data used in this study are mainly from government archives compiled by scholars (Chinese Academy of Governance, 2000), which cover all structural changes from 1949 to 1999 . To verify the information about recent waves of reform we refer to official websites and government gazettes (2000-2016). We use content analysis to elicit quantitative data from documents, and we recruited and trained two students to independently code the documents. We use Cohen's kappa ( $\kappa$ ) to gauge the inter-rater reliability of their coding, which is widely used in content analysis (Neuendorf, 2002). The average kappa of the 28 categories of our variables is 0.775 and all are significant at the 0.01 level, suggesting the coding is acceptable. The coding is mostly consistent for functions of agency birth (e.g., $\kappa=0.918$ for financial agencies) and modes of agency birth $(\kappa=0.770)$, while the reliability is relatively lower for types of agency birth $(\kappa=0.644)$. Given there are six possible forms of agency birth , they are understandably difficult to distinguish from one another. 


\section{Results}

The evolution of the central government apparatus

We first describe the profiles of central government units and then present evidence of their evolution. We divide the sample period into seven decades, during which the types, functions, and ranks of state structural entities have remained substantially consistent.

The number of central governmental units has, however, fluctuated radically during our sample period, ranging from thirty-two during the Cultural Revolution (1966-1975) to 100 at the beginning of the Reform and Opening-up (1976-1981) (see Figure 1). The number of central organizational units increased after the PRC was founded, owing to rapid industrialization following in the footsteps of the former Soviet Union (19511953). Given increasing fiscal burdens and human redundancy, the central government cut the number of units from eighty to roughly sixty in the late 1950s. The number of units quickly returned to about eighty in the early 1960s, and would have gone on increasing incrementally had not Chairman Mao ushered in the Cultural Revolution. Given that economic entities made up the lion's share in the reform era, the number of units soared to 100 in the early 1980s. Nevertheless, the number of units was cut to about sixty in the late 1980s, but rose over eighty again in the early 1990s. Although the number of ministries, commissions, and agencies has steadily decreased over the past three decades, the total number of central bodies still plateaus around eighty. The two recent rounds of super-ministry reform aimed to reduce the number of ministries/commissions/agencies, but the total number of central units has remained the same. Part of the reason is that former ministries and commissions were transformed into state bureaus and bureaus, which are still affiliated with or under the SC.

Insert Figure 1 about here. 
The top two types of body (ministries/commissions and organizations) directly under the SC account for about 80 percent of the total (see Table 1). Administrations and bureaus subordinate to ministries and commissions emerged as the third-largest group between 1989 and 1999 and as the second-largest from 2009 onwards, suggesting they were favored during the recent reform waves. Given the increasing complexity and professionalism of policy decision-making and implementation, the government has to rely on its subordinate organizations to coordinate units at lower levels. Their increase also reflects a kind of agencification, which is largely in line with the recent reform trend in many Western countries.

Insert Table 1 about here.

The rank of central governmental units mostly remained the same during the sample period. Roughly 60 percent of bodies are at ministry level, while most of the remainder (about 40 percent) are at vice-ministry level. Only about two percent are at bureau level.

Insert Table 2 about here.

We find interesting patterns and evolutions in the functions of central units. Economic development and social policy are the two largest policy areas across all periods, accounting for about 60 percent of the total. Economic development was strong during the first three decades, while social policy peaked in later decades. Social policy was highlighted to maintain social stability and equity, which is an underlying condition for support for the regime and for public legitimacy of the ruling party. Given the momentum of economic growth in state building and survival in the nascent stage, it is also understandable that agencies dedicated to economic development were prioritized. It is intriguing that central government units in charge of resources and environment have also increased in the last two decades (by about 12 percent), suggesting that the government has been paying more attention to environmental protection and resource conservation. The functional changes in central bodies largely mirror the stages of 
economic growth and social transformation, although administrative change usually lags behind socioeconomic change.

Insert Table 3 about here.

\section{Organizational changes in the central governmental apparatus}

The first seven decades of the PRC witnessed a total of 972 organizational changes. Of these, about 40 percent were births (396), 32 percent (310) were deaths, and 22 percent (266) were survivals (see Table 4). Organizational changes were most frequent in the first (1949-1958) and fourth decades (1979-1988), both accounting for about one quarter of total changes. Organizational change was at its lowest in the most recent two decades (4.5 percent from 1999 to 2008 and 1.8 percent from 2009 onwards) and between 1959 and 1968 (9.3 percent). Given that the bureaucratic apparatus has become increasingly routinized and inert, substantial restructuring tends to present a major challenge. Institutional reforms tend to consist of tinkering and adjustments, particularly in the two most recent rounds of reform.

Insert Table 4 and Figure 2 about here.

Among the eight types of unit birth, about half (49 percent) were pure i.e. the creation of new bodies without any prior organizational history, followed by foundings brought about by changing an organization's name (18 percent). Units were less likely to be created through succession ( 7 percent), merging ( 8 percent), complex reorganizations (9 percent), and splitting ( 6 percent), while less than two percent were accounted for by absorption and change of affiliation or rank order. ${ }^{4}$

In terms of survival, the most frequent change of function was size (the expansion or shrinking of the scope of responsibility) (50 percent), followed by change of superior

\footnotetext{
${ }^{4}$ The tables showing more detailed results have been omitted here to save space.
} 
organization (horizontal movement) (18 percent), maintenance by absorption (10 percent), and succession (9 percent). Other types of survival were few, including change in function, change of name, change of type, change of affiliation or rank, and complex changes (different types of changes that happen at the same time).

As for government unit death, entities were most likely to be ended by merging (27 percent) or by changing their name (23 percent), followed by pure termination (18 percent) or by absorption (16 percent). Other types of death were seldom, including ending by splitting, by complex reorganization, or by being converted into a public service institution or SOE.

The types of organizational change evolved during the sample period. In terms of the three types of organizational change, the birth of new units peaked in the first decade (38 percent), followed by the Reform and Opening-up period (1979-1988) (25 percent). It is understandable that new regimes usually require new organizational units to be created from scratch. Economic growth replaced the predominance of ideological confrontation and political campaigns in the late 1970s, which witnessed the establishment of new entities dedicated to macroeconomic management and industrial regulation. As the state apparatus gradually stabilized, few new units were created.

Survivals were mostly found during the fourth and fifth decades (1979-1988 and 1989-1999), accounting for 27 and 29 percent respectively. Unlike in prior decades, existing bodies were often restructured in various ways rather new ones being created, indicating a maturing of the structure.

Deaths of government units occurred most frequently between 1949 and 1958 and between 1979 and 1988, accounting for 23 and 27 percent respectively. The Reform and Opening-up essentially transformed the centrally planned economic system into a market-based system, which entailed abolishing many outdated entities. The National Development and Reform Commission, for instance, replaced the State Development Planning Commission, and many ministries in charge of specific industries were abolished (e.g., metallurgy, textiles, and coal). When the PRC was founded it experimented with significant organizational changes back and forth, which is usual for new regimes. 
Insert Table 5 about here.

With regard to the modes of governmental change, we find that legislation (59.6 percent) was used more than executive orders (see Table 5). Unit birth and death were more likely to be effected by legislation passed by the National People's Congress (NPC), which endows entities with statutory authority. In the case of unit survival, however, executive orders issued by SC were more frequently used (55.6 percent). Unit survival is routine organizational change, and executive orders can handle it. The birth and death of bodies, in contrast, are more pertinent to the legal authority of NPC.

\section{Discussion and conclusion}

Apart from economic booms and societal transformation, structural changes in the central government apparatus in China are largely shaped by political cycles, which is what we would expect in a one-party state, seen from the polity elements. The political cycle of the first 70 years of the PRC can be framed by at least two dimensions. The first is to consider the key political changes, including the early days of the PRC (19491965), the Cultural Revolution (1966-1976), and the Reform and Opening-up (1977- ). The second is to use the incumbent political leaders in this period as a point of departure (President of the PRC or General Secretary of the CPC). These were Mao Zedong (1949-1976), Deng Xiaoping (1977-1992), Jiang Zemin (1993-2002), Hu Jintao (2003-2012), and Xi Jinping (2013- ). As mentioned above, the founding of the PRC gave birth to many new administrative units, but immature changes soon resulted in many unit deaths. Numerous local governments were jeopardized in the turmoil of the Cultural Revolution, but central units were by and large controlled and maintained by the SC. The Reform and Opening-up triggered a wave of organizational change, including the abolition of outdated organizational entities and the creation of new ones. The will of national leaders therefore plays a vital role in shaping the patterns of organizational change at central level. 
If we use the transformative model to interpret our main results, starting from the polity elements and their dynamic relationship to the environmental and cultural ones, the main pattern is breaks and discontinuity rather than continuity -i.e. external shocks instigated 'punctuated equilibriums' at critical junctures (cf. Baumgartner and Jones 1993). Using the cultural elements, we can point to the simple fact that the establishment of the PRC in 1949 necessarily implies a substantial break with the past. A new regime needs a new set of institutions and this is reflected in the rather strong increase in organizational units in the decade after 1949. The Cultural Revolution was also a major shock, leading to a substantial decrease in the number of central structural units. After this period, the Reform and Opening-Up was another shock and the number of units peaked during this period, while the real start of economic growth and marketization from 1992 onwards has kept the number of structural entities at a high level. Our take on this is that cultural changes reinforce and support changes initiated by the political leadership.

We also see change and turbulence within the different periods. The periods 19491958 and 1979-1988 saw the highest percentage of organizational births and deaths (Table 4), meaning that many structural units established did not survive, probably because the rationale for their establishment was weak and they ran into problems functioning in a new structural landscape, something Kaufman (1976) pointed out as a reason for newly established federal organizations in the US not surviving their first years. This could also be seen as a struggle to find their niche among public organizations (cf. Hannan and Freeman 1989).

Amidst the discontinuities pointed out, what are the continuities? Since the two decades after 1979 exhibited the highest survival rates for agencies in this half-century period, it is obvious that a certain share of the original government units managed to survive long-term, but also that the Reform and Opening-Up period created bodies that survived into the 1990s and further on.

The polity factors are very much connected to the structural unit pattern found, in particular the discontinuities and breaks. In a one-party state with strong political leaders, the latter will have a much bigger say in the shape of the administrative 
structure, including the structural units of the central apparatus, than political leaders in Western democracies (Rothstein, 2014). During their period of rule, every set of leaders, will act as entrepreneurs of change, i.e. in our case structural changes, creating much greater fluctuations in structure. In his book dealing with problems of implementing reforms, Patashnik (2008) argues that the lack of reform success is mostly a result of a different set of actors deciding on and implementing reforms. We will argue that such a problem will be less important in the case of reforms in the central civil service of China because of much stronger overall political control.

The third set of plausible reasons deals with the technical and institutional environment. The technical environment in the form of an internal war in China was obviously important for the establishment of government units after 1949, as was the industrialization in this period. After the Cultural Revolution, the need for economic, social, and technical improvements was acute, leading to major changes in the central administrative apparatus. Similarly, in the 1990s, there was an urgent need to match the wish for strong economic growth with a mature structure at the central level. Political leaders' actions both reflected environmental needs and supported such changes through diverse structural change.

Concerning the institutional environment, our data allow us to draw far fewer conclusions than case data do. The relatively large number of central government units related to social policy in a system with a rather low level of social and health benefits together with the symbolic features of administrative development (which was probably even more typical during the period of strong economic growth that began in the 1990s) may indicate that the political leadership was worried about social development. Furthermore, we know that the Reform and Opening-Up period from the late 1970s aimed to 'stream-line' the central administrative apparatus but met with strong resistance from the leaders of the ministries and agencies, making it sometimes difficult to implement (Christensen, et al., 2008). This probably meant some of the administrative changes had symbolic features and were designed to signal political capacity to gain support and legitimacy in the population, but also to remedy internal cultural resistance in the governmental administration (Lan, 2001). 
We have mapped structural change in the central government apparatus in China in the first seven decades since the establishment of the PRC, and have found interesting patterns of organizational change in function, rank, and type. But overall there is a dynamic relationship between administrative change and ministerial structure. During the last decade or so the Chinese government has created a handful of super-ministries imitating the practice of Western countries, reflecting a post-NPM feature (Dong, et al., 2010). Moreover, it has restructured its apparatus in almost every term of office to cut various units and downsize the workforce. Ministries and commissions have been demoted to state bureaus and other vice-ministry agencies, but they can still report directly to the SC. In other words, the cross-agency coordination dilemma has not been resolved but rather internalized under the umbrella of ministries and commissions. There are no more than thirty ministries and commissions, but the SC still manages a total of eighty central administrative units.

In a comparative perspective, Chinese central structural changes seem to be more characterized by political cycles and political-executive control than in Western countries (Rothstein, 2014). A typical similarity is, however, that a lot of reform and change initiatives both reflect and influence broad societal development features and are aimed at increasing legitimacy and support: they likewise encounter cultural and other resistance and difficulties of implementation (March and Olson, 1983; Patashnik, 2008).

\section{References}

Aberbach JD and Christensen T (2001) Radical reform in New Zealand: Crisis, windows of opportunity, and rational actors. Public Administration 79(2): 403422.

Aberbach JD and Christensen T (2014) Why reforms so often disappoint. The American Review of Public Administration 44(1): 3-16.

Adam C, Bauer MW, Knill C and Studinger P (2007) The termination of public organizations: Theoretical perspectives to revitalize a promising research area. Public Organization Review 7(3): 221-236.

Boin A, Kuipers S and Steenbergen M (2010) The life and death of public organizations: A question of institutional design? Governance 23(3): 385-410.

Brunsson N (1989) The organization of hypocrisy: Talk, decisions and actions in 
organizations. Chichester: John Wiley \& Sons.

Carpenter DP and Lewis DE (2004) Political learning from rare events: Poisson inference, fiscal constraints, and the lifetime of bureaus. Political Analysis 12(3): 201-232.

Chinese Academy of Governance (ed.). (2000) Fifty years of government structures in the people's republic of China, 1949-1999. Beijing: Party Building Books Publishing House.

Christensen T, Dong L and Painter M (2008) Administrative reform in China's central government -- how much 'learning from the West'? International Review of Administrative Sciences 74(3): 351-371.

Christensen $\mathrm{T}$ and Lægreid P (eds.). (2001) New Public Management: The transformation of ideas and practice. Aldershot: Ashgate.

Dong L, Christensen T and Painter M (2010) A case study of China's administrative reform: The importation of the super-department. The American Review of Public Administration 40(2): 170-188.

James O, Petrovsky N, Moseley A and Boyne GA (2016) The politics of agency death: Ministers and the survival of government agencies in a parliamentary system. British Journal of Political Science 46(4): 763-784.

Kaufman H (1976) Are government organizations immortal? Washington, DC: The Brookings Institution.

Kingdon JW (1984) Agendas, alternatives, and public policies. Boston: Little, Brown.

Kuipers S, Yesilkagit K and Carroll B (2017) Coming to terms with termination of public organizations. Public Organization Review: doi: 10.1007/s11115-1101710376-11114.

Lan Z (2001) Understanding China's administrative reform. Public Administration Quarterly 24(4): 437-468.

Lewis DE (2002) The politics of agency termination: Confronting the myth of agency immortality. The Journal of Politics 64(1): 89-107.

Ma L (2016) Does super-department reform improve public service performance in China? Public Management Review 18(3): 369-391.

March JG and Olson JP (1983) Organizing political life: What administrative reorganization tells us about government. The American Political Science Review 77(2): 281-296.

Meyer JW and Rowan B (1977) Institutionalized organizations: Formal structure as myth and ceremony. The American Journal of Sociology 83(2): 340-363.

Neuendorf KA (2002) The content analysis guidebook. Thousand Oaks, CA: Sage Publications.

Olsen JP (1992) Analyzing institutional dynamics. Staatswissenschaften und Staatspraxis 2: 247-271.

Patashnik EM (2008) Reforms at risk: What happens after major policy changes are enacted. Princeton, NJ: Princeton University Press.

Pearson MM (2007) Governing the Chinese economy: Regulatory reform in the service of the state. Public Administration Review 67(4): 718-730.

Pollitt C and Bouckaert G (2011) Public management reform: A comparative analysis 
- New Public Management, governance, and the neo-weberian state (3rd ed.). Oxford: Oxford University Press.

Rolland VW and Roness PG (2011) Mapping organizational units in the state: Challenges and classifications. International Journal of Public Administration 33(10): 463-473.

Rolland VW and Roness PG (2011) Mapping organizational change in the state: Challenges and classifications. International Journal of Public Administration 34(6): 399-409.

Rolland VW and Roness PG (2012) Foundings and terminations: Organizational change in the Norwegian state administration 1947-2011. International Journal of Public Administration 35(12): 783-794.

Rothstein B (2014) The Chinese paradox of high growth and low quality of government: The cadre organization meets Max Weber. Governance 28(4): 533-548.

Sahlin-Andersson K. (2001). National, international and transnational construction of New Public Management. In: Christensen T and Lægreid P (eds) New Public Management: The transformation of ideas and practice. Aldershot: Ashgate.

Schattschneider EE (1960) The semi-sovereign people: A realist's view of democracy in America. Illinois: The Dryden Press.

Selznick P (1957) Leadership in administration. New York: Harper \& Row.

Verhoest K, Van Thiel S, Bouckaert G and Lægreid P (eds.). (2012) Government agencies: Practices and lessons from 30 countries. New York: Palgrave Macmillan.

Weaver RK and Rockman BA (1993) Do institutions matter?: Government capabilities in the United States and abroad. Washington, D.C.: Brookings Institution Press.

Westney DE (1986) Imitation and innovation. Cambridge, MA: Harvard University Press.

Wolin SS (2009) Politics and vision: Continuity and innovation in Western political thought. Boston: Little, Brown. 


\section{Tables and figures}

Table 1. Types of central governmental unit from 1949 to 2016

\begin{tabular}{|c|c|c|c|c|c|c|c|c|}
\hline Type & $\begin{array}{l}1949- \\
1958\end{array}$ & $\begin{array}{l}1959- \\
1968\end{array}$ & $\begin{array}{l}1969- \\
1978\end{array}$ & $\begin{array}{l}1979- \\
1988\end{array}$ & $\begin{array}{l}1989- \\
1999\end{array}$ & $\begin{array}{l}1999- \\
2008\end{array}$ & $2009-$ & Total \\
\hline (1) General & & & & & & & & \\
\hline $\begin{array}{l}\text { Office } \\
\text { (2) Ministries }\end{array}$ & 1.5 & 1.3 & 1.3 & 1.2 & 0.0 & 0.0 & 0.0 & 0.7 \\
\hline and commissions & 59.1 & 60.3 & 47.4 & 43.9 & 33.7 & 30.3 & 27.6 & 42.2 \\
\hline (3) Offices & 10.6 & 9.0 & 6.6 & 6.1 & 8.4 & 7.9 & 8.0 & 8.0 \\
\hline (4) Organizations & 27.3 & 26.9 & 39.5 & 28.0 & 27.7 & 23.6 & 25.3 & 28.2 \\
\hline $\begin{array}{l}\text { (5) Public service } \\
\text { institutions } \\
\text { (6) }\end{array}$ & 0.0 & 0.0 & 0.0 & 1.2 & 8.4 & 10.1 & 10.3 & 4.6 \\
\hline $\begin{array}{l}\text { Administrations } \\
\text { and bureaus } \\
\text { (7) Industrial }\end{array}$ & 0.0 & 0.0 & 2.6 & 15.9 & 18.1 & 24.7 & 25.3 & 13.2 \\
\hline Associations & 1.5 & 2.6 & 2.6 & 3.7 & 3.6 & 3.4 & 3.4 & 3.0 \\
\hline Total & 100 & 100 & 100 & 100 & 100 & 100 & 100 & 100 \\
\hline
\end{tabular}

Note: The cells represent column percentages.

Table 2. The ranks of central governmental units from 1949 to 2016

\begin{tabular}{lllllllll}
\hline Rank & $1949-$ & $1959-$ & $1969-$ & $1979-$ & $1989-$ & $1999-$ & $2009-$ & Total \\
& 1958 & 1968 & 1978 & 1988 & 1999 & 2008 & & \\
\hline $\begin{array}{l}\text { Ministry-level } \\
\text { Vice-Ministry- }\end{array}$ & 69.7 & 71.8 & 72.4 & 50.0 & 50.6 & 50.6 & 50.6 & 58.6 \\
level & 27.3 & 25.6 & 26.3 & 48.8 & 48.2 & 46.1 & 46.0 & 39.0 \\
Bureau-level & 3.0 & 2.6 & 1.3 & 1.2 & 1.2 & 3.4 & 3.4 & 2.3 \\
Total & 100 & 100 & 100 & 100 & 100 & 100 & 100 & 100 \\
\hline
\end{tabular}

Note: The cells represent column percentages. 
Table 3. The functions of central governmental units from 1949 to 2016

\begin{tabular}{|c|c|c|c|c|c|c|c|c|}
\hline Function & $\begin{array}{l}1949- \\
1958 \\
\end{array}$ & $\begin{array}{l}1959- \\
1968 \\
\end{array}$ & $\begin{array}{l}1969- \\
1978 \\
\end{array}$ & $\begin{array}{l}1979- \\
1988 \\
\end{array}$ & $\begin{array}{l}1989- \\
1999 \\
\end{array}$ & $\begin{array}{l}1999- \\
2008\end{array}$ & $2009-$ & Total \\
\hline Foreign Affairs & 9.1 & 9.0 & 7.9 & 9.8 & 9.6 & 6.7 & 6.9 & 8.4 \\
\hline $\begin{array}{l}\text { Social Policy } \\
\text { Monetary }\end{array}$ & 37.9 & 30.8 & 28.9 & 35.4 & 37.3 & 37.1 & 34.5 & 34.6 \\
\hline $\begin{array}{l}\text { Policy } \\
\text { Economic }\end{array}$ & 6.1 & 6.4 & 3.9 & 6.1 & 6.0 & 6.7 & 6.9 & 6.1 \\
\hline $\begin{array}{l}\text { Development } \\
\text { Resources and }\end{array}$ & 22.7 & 28.2 & 28.9 & 17.1 & 14.5 & 20.2 & 20.7 & 21.6 \\
\hline $\begin{array}{l}\text { Environment } \\
\text { Research and }\end{array}$ & 9.1 & 10.3 & 7.9 & 13.4 & 10.8 & 12.4 & 12.6 & 11.1 \\
\hline Consultation & 6.1 & 6.4 & 10.5 & 11.0 & 14.5 & 11.2 & 11.5 & 10.3 \\
\hline General & 9.1 & 9.0 & 11.8 & 7.3 & 7.2 & 5.6 & 6.9 & 8.0 \\
\hline Total & 100 & 100 & 100 & 100 & 100 & 100 & 100 & 100 \\
\hline
\end{tabular}

Note: The cells represent column percentages.

Table 4. Types of organizational change from 1949 to 2016

\begin{tabular}{lcccccccc}
\hline Change & $1949-$ & $1959-$ & $1969-$ & $1979-$ & $1989-$ & $1999-$ & $2009-$ & Total \\
& 1958 & 1968 & 1978 & 1988 & 1998 & 2008 & & \\
\hline Birth & 138 & 33 & 58 & 91 & 47 & 23 & 6 & 396 \\
$(\%)$ & 34.9 & 8.3 & 14.7 & 23.0 & 11.9 & 5.8 & 1.5 & 100 \\
Survival & 33 & 36 & 43 & 71 & 76 & 4 & 3 & 266 \\
$(\%)$ & 12.4 & 13.5 & 16.2 & 26.7 & 28.6 & 1.5 & 1.1 & 100 \\
Death & 72 & 21 & 60 & 85 & 47 & 17 & 8 & 310 \\
$(\%)$ & 23.2 & 6.8 & 19.4 & 27.4 & 15.2 & 5.5 & 2.6 & 100 \\
Total & 243 & 90 & 161 & 247 & 170 & 44 & 17 & 972 \\
$(\%)$ & 25.0 & 9.3 & 16.6 & 25.4 & 17.5 & 4.5 & 1.8 & 100 \\
\hline
\end{tabular}

Note: For each type of organizational change, the first and second rows represent frequency and row percentage respectively.

Table 5. Modes of organizational change from 1949 to 2016

\begin{tabular}{|l|c|c|c|c|}
\hline \multirow{2}{*}{ Mode of change } & \multicolumn{3}{|c|}{ Types of organizational change } & \multirow{2}{*}{ Total } \\
\cline { 2 - 4 } & Birth & Survival & Death & \\
\hline Executive order & 34.9 & 55.6 & 34.5 & 40.4 \\
\hline Legislation & 65.2 & 44.4 & 65.5 & 59.6 \\
\hline Total & 100 & 100 & 100 & 100 \\
\hline
\end{tabular}

Note: For each type of organizational change, the cells represent the column percentage. 


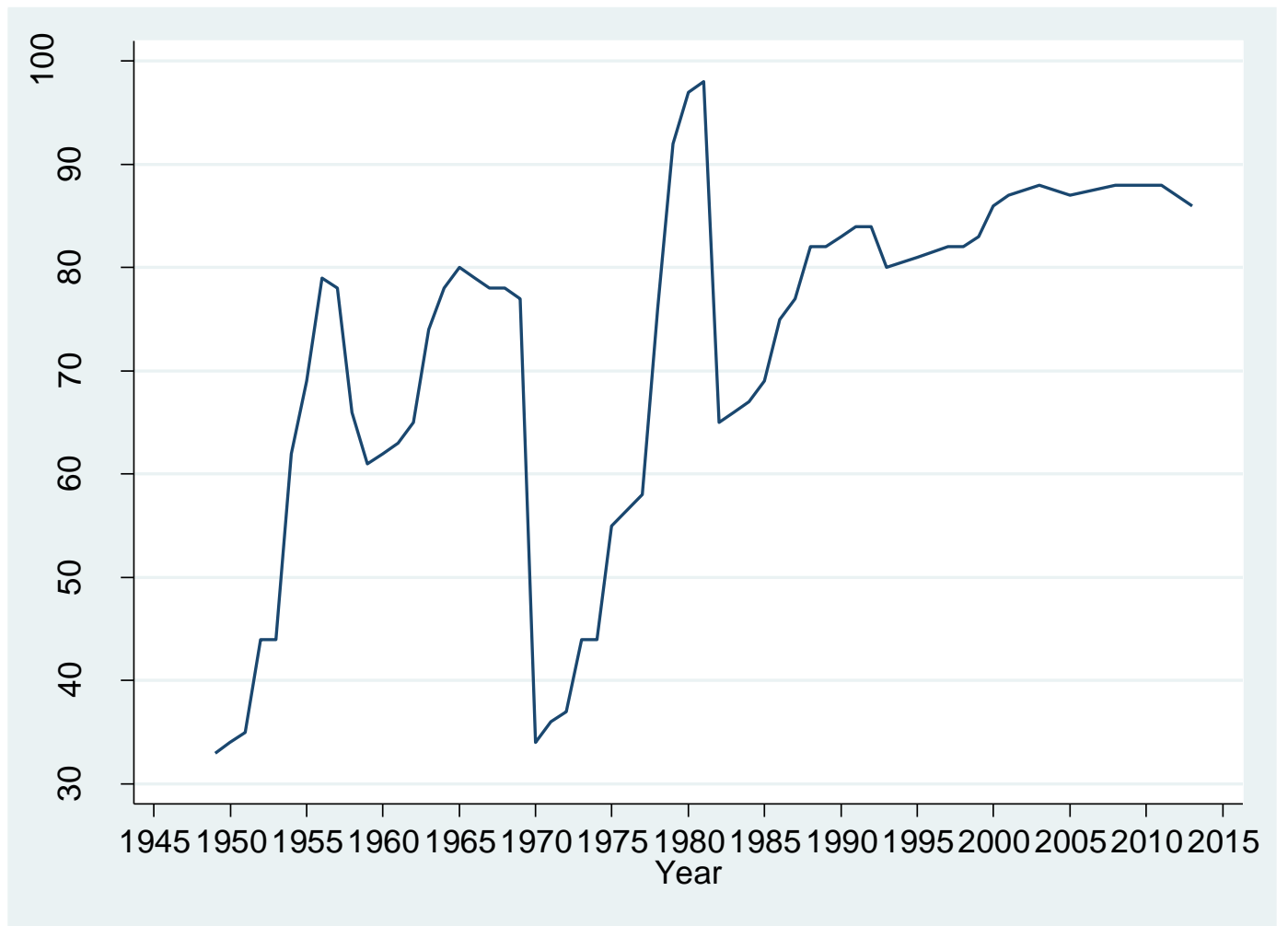

Figure 1. Fluctuations in the number of central governmental units over the years (1949-2016)

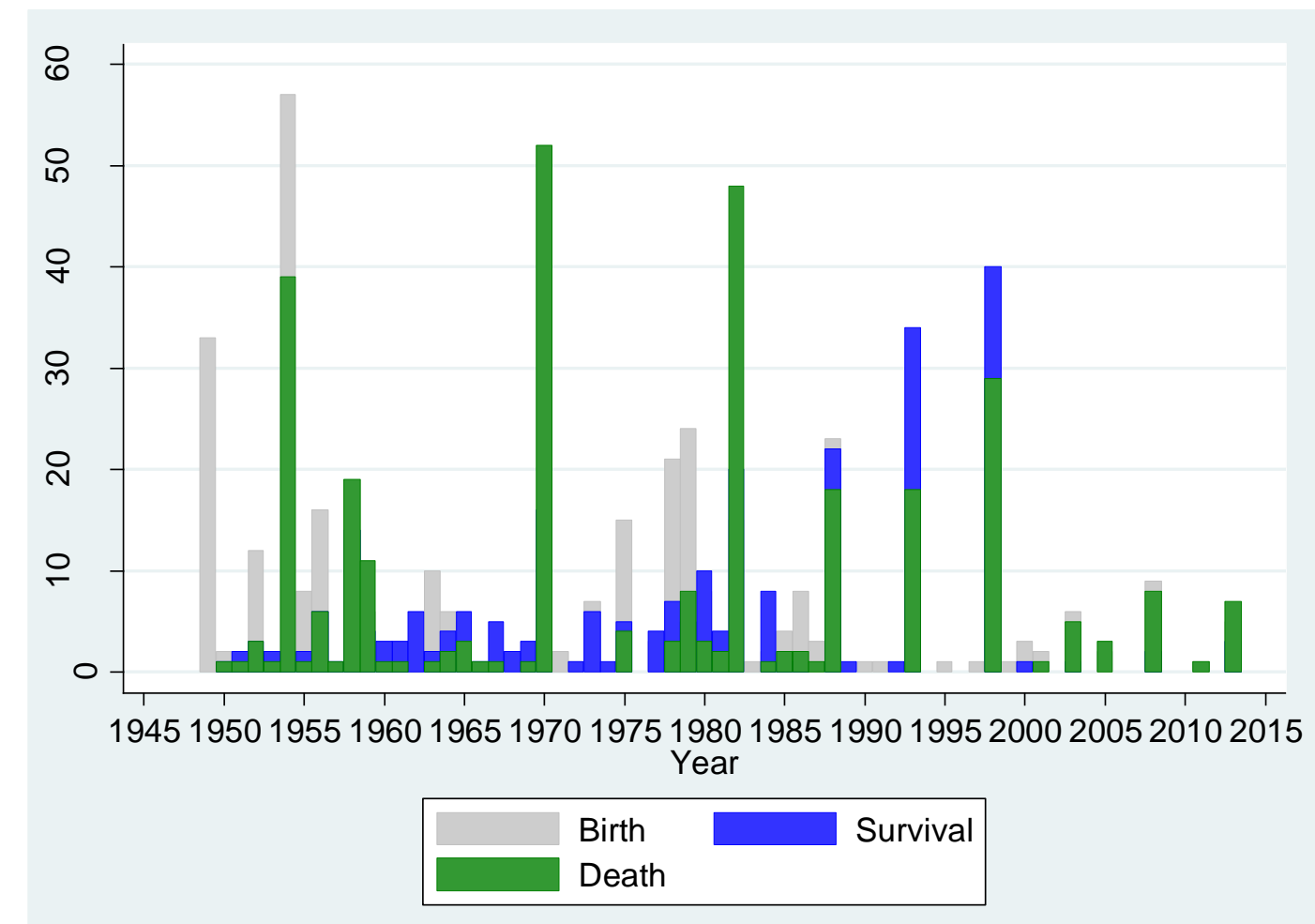

Figure 2. Fluctuations in types of organizational change over the years (1949-2016) 